\title{
Overview of Forestry Sector in Peninsular Malaysia
}

\author{
Izaidah Talib
}

\begin{abstract}
School of Forest Economics and Management, Beijing Forestry University, 35 Qinghua Donglu, Beijing, 100083 Beijing, China
\end{abstract}

\begin{abstract}
Forests have played an important role in the resource-based socio-economic development of Malaysia. Malaysia, located in South East Asia, comprises Peninsular Malaysia and the states of Sabah and Sarawak. In accordance with Malaysia's Federal Constitution, the legislative control of land and forests is a state matter and the state governments have complete jurisdiction over their respective forest resources. This paper is concerned with the forestry sector in Peninsular Malaysia. It describes and discuss the current status of forest in Peninsular Malaysia in terms of its policy and legislation, forest administration, forest management system under sustainable forest management, forest resources and wood-based industries.
\end{abstract}

Keywords: Forest, current status, forestry, sustainable forest management, Peninsular Malaysia

\section{INTRODUCTION}

Malaysia, located in South East Asia, comprises Peninsular Malaysia and the states of Sabah and Sarawak along with the Federal Territory of Labuan on the island of Borneo. The total area is $329,750 \mathrm{~km}^{2}$ and contains a varied topography ranging from coastal areas to mountainous regions. Malaysia is bounded over by a coastline of $4800 \mathrm{~km}$. The climate is tropical with mean daily temperatures of between $26^{\circ} \mathrm{C}$ to $28^{\circ} \mathrm{C}$. Two monsoon periods occur between November-March and May-September. Rainfall is abundant, averaging $2,000 \mathrm{~mm}$ to $4,000 \mathrm{~mm}$ annually. Clouds cut off a substantial amount of direct sunlight in the afternoon and evening. Malaysia receives about 6 hours of direct sunlight daily. Malaysia's forests are very rich in species and are extremely complex ecosystems. In $2000,56 \%$ of total land area was forested whilst in 2007, it was $55 \%$. Malaysia is also considered one of the world's mega-diverse countries and ranked 12th in the world on the National Biodiversity Index (NRE, 2011). Forests have played an important role in the resource-based socioeconomic development of Malaysia. In accordance with Malaysia's Federal Constitution, the legislative control of land and forests is a state matter and the state governments have complete jurisdiction over their respective forest resources. This paper is concerned with the forestry sector in Peninsular Malaysia. It describes and discuss the current status of forestry in Peninsular Malaysia in terms of its policy and legislation, forest administration, forest management system under sustainable forest management (SFM), forest resources and wood-based industries.

\section{METHODS AND LITERATURE REVIEW}

In order to provide this paper, the information and data related to the topic were obtained from the research literature, official records, etc. The articles were taken from review ad revise the journals in official website and YAHOO (www.yahoo.com). The articles were selected by first typing appropriate words and the revising the abstract of the exposed journal articles.

\section{POLICY AND LEGISLATION}

In accordance with Malaysia's Federal Constitution, the legislative control of land and forests is a state matter and the state governments have complete jurisdiction over their respective forest resources. However, the federal government does provide technical advice on forest management and development, undertakes research and education, and promotes industrial development of wood-based industries and trade.

In order to facilitate the adoption of a coordinated and common approach to forestry, as well as reconcile cross-sectoral policies that interface with the forestry sector, the National Forestry Council (NFC) was established on 20 December 1971 by the National Land Council (NLC). The NLC is empowered under the Malaysian Constitution to formulate a national policy for the promotion and control of utilisation of

This article is published under the terms of the Creative Commons Attribution License 4.0

Author(s) retain the copyright of this article. Publication rights with Alkhaer Publications.

Published at: http://www.ijsciences.com/pub/issue/2015-12/

DOI: 10.18483/ijSci.882; Online ISSN: 2305-3925; Print ISSN: 2410-4477 
land for mining, agriculture and forestry. The NFC serves as a forum for the Federal and the State Governments to discuss and resolve common problems and issues relating to forestry policy, administration and management, as well as to enhance co-operation between the Federal and State Governments, so as to ensure a coordinated approach in the implementation of policies and programmes related to forestry. All the decisions of the NFC have to be endorsed by the NLC. The responsibility for implementing the decisions of the NFC lies with the State Governments unless it is within the authority of the Federal Government.

In 1978, National Forestry Policy 1978 was formulated and approved by the NFC which is currently being implemented by all the States in Peninsular Malaysia, while the objectives of this policy are also being implemented in Sabah. In Sarawak, the Forest Policy 1954 which has very similar provisions to the National Forestry Policy remains the basis for forestry practices. In this regard, the National Forestry Policy calls for the establishment of a Permanent Forest Estate (Permanent Reserved Forests) to be classified and managed under four major functions, namely, Protection Forest, Production Forest, Amenity Forest, and Research and Education Forest.

In 1992, the National Forestry Policy 1978 was revised to include the importance of biological diversity conservation and the sustainable utilisation of forest genetic resources, as well as the role of local communities in forest development. In line with the revised NFP, the National Forestry Act 1984 was also amended in 1993 to incorporate additional provision for SFM, by way of including more stringent penalties for forest offences including, among others, the illegal felling of tree and to provide for mandatory imprisonment for convicted illegal loggers. The police and armed forces were given new powers of surveillance in the forestry sector, with the aim of curbing illegal logging, encroachment into forest areas and timber theft. The National Forestry Act is adopted for implementation by all the states and is complemented by relevant laws dealing with land and water conservation, environmental quality, wildlife protection, the management of national parks, biodiversity conservation, and the rights of indigenous communities.

To ensure effective forest management and the implementation of the National Forestry Policy in Malaysia, various forestry enactments and ordinances were formulated and enforced by the respective state authorities since the early 1900s. Other legislation which are considered of major importance to the forestry sector apart from the National Forestry Act, 1984 (Amendment 1993) and the Wood-based Industries Act, 1984 are as follows:
- National Land Code 1965;

- Penal Code (FMS Cap. 45), 1948 (Amendment 1993);

- Criminal Procedure Code (FMS Cap.6) 1903 (Amendment 1995);

- Evidence Act 1950 (Amendment 1993);

- Financial Procedure Act 1967 (Amendment 1993);

- Water Enactment 1935;

- Land Conservation Act 1960;

- Protection Of Wildlife Act 1972 (Amendment 1976 \& 1988);

- Malaysian Timber Industry Board Act 1973;

- Environmental Quality Act 1974 (Amendment 1995);

- National Park Act 1980 (Amendment 1983);

- Malaysian Forestry Research and Development Board Act 1985;

- Mining Enactment 1926;

- Local Government Act 1976;

- Biosafety Act 2007

\section{FORESTRY ADMINISTRATION}

Forestry administration in Peninsular Malaysia can be divided into three levels, namely the Federal, State and district levels. There are eleven states in Peninsular Malaysia i.e. Johor, Kedah, Kelantan, Melaka, Negeri Sembilan, Pahang, Perak, Perlis, Pulau Pinang, and Terengganu. Each state has its own forestry department headed by the State Director of Forestry who is responsible to the Chief Minister of the state. At the state level, the State Director of Forestry is usually assisted by two Deputy Directors (Forest Development and Forest Operation) and other officers, namely Forest Management Officer and Silvicultural Officer. The District Forest Officer assisted by a deputy and several uniform field staffs' heads forestry administration at the district level. The District Forest Officers report directly to the State Director of Forestry.

The state forestry department is responsible for the implementation of the forest policies of the state. At the Federal level, the Director General who is answerable to the Federal Minister of Natural Resources and Environment (NRE) heads the administration. He is assisted by two deputies and several directors. The main responsibility of the federal forestry department is to give technical advice to the state forestry departments as well as policy advice to the federal government. Professional and sub professional foresters are appointed by the federal government and seconded to the state governments.

\section{SUSTAINABLE FOREST MANAGEMENT (SFM)}

Malaysia has defined the sustainable forest management (SFM) according to ITTO definition as the process of managing permanent forest areas to achieve one or more management objectives for 
purposes of producing clearly defined goods and services in perpetuity without any reduction in value and productivity while generating no undesirable effects on the social and physical environment (ITTO, 1998). Peninsular Malaysia has long recognized the need for sustainable management and development in the invaluable forest resources that vital for socioeconomic development to benefit of both present and future generations. The forest management practices in Peninsular Malaysia had been subjected to constant review and refinement to keep abreast with the latest development in forestry and to meet the changing forest and market conditions.

\subsection{Forest Management System}

History of forest management system in Peninsular Malaysia is a good example changes in the involvement of multi disciplines inputs in the forest management. Early stage of the system is more oriented to the timber and other economic forest products demanded by the markets. In year $1900-$ 1910 was the era of 'Gutta percha', harvesting heavy hardwood (Chengal and Balau) and the silvicultural focus were on planting of Taban tree (Palaqium spp) for rubber (Gutta percha) production and planting of Chengal (Neobalanocarpus heimii) and Balau (Shorea spp) trees for high value timber.

Improvement felling system was then practiced in year 1911 - 1922 by focusing on the Taban tree management for rubber (Gutta percha) production and killing trees that were suppressing or competing with the high value timber trees. In year 1926 Regeneration Improvement Felling was introduced where the system focused on promoting natural growth of the heavy hardwood and light hardwood species. Malayan Uniform System (MUS) took place in year 1948 with the main aim was to establish more uniform stand with high value timber species through killing of noncommercial big trees. Silvicultural practice under the MUS system provides treatment to promote growth of the seedling, pole and advanced growth trees of the selected species.

In year 1978 the current Selective Management System (SMS) was introduced where the system flexible cutting regime is provided through various cutting options. The system takes into account the variation in the stand content and changes of economic-social factors. The main aim of SMS system is to optimize the management objectives i.e. economic felling, forest sustainability and minimising the cost of forest development. Under the SMS, the cutting limits prescribed for the group of dipterocarp species would range from 50-65 cm diameter at breast height (dbh) while those prescribed for the group of non-dipterocarp species would range from $45-55 \mathrm{~cm}$ $\mathrm{dbh}$, with the maximum volume allowed to be harvested being $85 \mathrm{~m}^{3} / \mathrm{ha}$. The difference in the cutting limits prescribed between the dipterocarp species and that of the non-dipterocarp species would be at least 5 $\mathrm{cm}$ in order to conserve a higher percentage of dipterocarp species for the next cut (Thang, H.C. 2009). It also requires a minimum residual stand of 32 trees per hectare after harvesting with the cutting cycle of 30 years.

\subsection{Malaysian Criteria and Indicators (MC\&I)}

As a member of the International Tropical Timber Organization (ITTO), Malaysia is fully committed to the achievement of sustainable forest management. In this respect, Malaysia has taken several measures to implement the ITTO guidelines for the sustainable management of natural tropical forests and its criteria for the measurement of sustainable tropical forest management.

Initiatives in the formulation of a set of criteria and indicators as a yardstick to assess sustainable forest management in Peninsular Malaysia started in 1994 based on the ITTO Criteria and Indicators for Sustainable Forest Management published in 1992. Consequently, a first draft of criteria and indicators known as Malaysian Criteria, Indicators, Activities and Management Specifications for Sustainable Forest Management was formulated. A pilot study on timber certification was tested in Pahang, Selangor and Terengganu in mid-1996. As a follow-up to the pilot study, several discussions were held in 1998 and 1999 taking into account the some related factors, opinions or developments and the output from the discussions was a document entitled Malaysian Criteria, Indicators, Activities and Standards of Performance (MC\&I) for Forest Management Certification (Forest Management Unit Level), Peninsular Malaysia dated 23 December 1999. This document is also commonly known as MC\&I (2001). In brief, the standards developed contain 6 criteria, 29 indicators, 87 activities and 247 standard of performances. The MC\&I (2001) implemented in eight (8) states namely Johor, Kedah, Kelantan, Negeri Sembilan, Pahang, Perak, Selangor and Terengganu have received few request for further enhancement with provisions for environmental protection, ecology, social and conservation of biological diversity. Outcomes of the review, Malaysian Criteria and Indicators for Forest Management Certification [MC\&I (2002)] has been adopted as documentation standard for forest management certification in 2004 with contain of 9 principles, 47 criteria, 96 indicators and 233 verifiers.

In line with international practices and standards setting process for the development of certification standards adopted under Malaysian Timber Certification Scheme (MTCS), certification standards used need to be reviewed at least every five (5) years to ensure continuous improvement. The Standards Review Committee (SRC) a forum for various stakeholders was established and assigned to review the MC\&I (2002) and to develop the revised standard. 
Malaysian Timber Certification Council (MTCC) served as the Secretariat of the SRC and plays a role in facilitating the formation of the SRC. After making improvement and changes, Standard MC\&I (Natural Forest) can be summarized as 9 principles, 47 criteria, 97 indicator, and 307 verifiers.

All eight (8) FMUs in Peninsular Malaysia namely Johor, Kedah, Kelantan, Negeri Sembilan, Pahang, Perak, Selangor and Terengganu have been switching from MC\&I (2002) to implement the requirements of the MC\&I (Forest Natural) by June 1, 2013. All FMUs are in compliance with standard MC\&I (Natural Forest) and awarded the new certificate valid for a period of three (3) years beginning 2013. Until December 31, 2014, eight (8) FMUs in Peninsular Malaysia covering an area of 4.51 million hectares Permanent Reserved Forest has successfully maintained the Forest Management Certification in accordance with Standard MC\&I (Natural Forest) certified by Certification Bodies namely SIRIM QAS International Sdn. Bhd. and SGS (M) Sdn. Bhd.

Although the recent Forest Management Certification conducted focuses to meet the demands and requirements of the international consumer market (International Consumer Demand), the participation of Forestry Department Peninsular Malaysia (FDPM) in the Forest Certification is voluntary. The participation of FDPM and all the State Forestry Departments in Peninsula Malaysia is the need of high commitments to realize the importance of maintaining the role and contribution of national forest resources, particularly the Permanent Reserved Forest under the Sustainable Forest Management practices for the benefits of the present and future generations.

\subsection{Forest Resources}

The tropical rain forests of Malaysia are extremely complex ecosystems and are richer in tree species than in similar areas of Africa and South America. They are, in fact, the most species rich plant communities known anywhere in the world (Whitmore 1975) and have evolved over millions of years. There are at least 15,000 species of flowering plants, of which 2,500 are tree species; 286 species of mammals; 600 species of birds; 140 species of snakes; 150 species of frogs and thousands of species of insects, many of which are still being documented. In addition, over 1,300 plant species have been identified as having potential pharmaceutical properties with some of them currently being used as traditional herbal medicine (Thang, H.C. 2009). In Peninsular Malaysia is estimated to contain 8,000 flowering plants, a total 2,650 species are tree species with 890 of them reaching harvestable sizes of at least 45cm dbh (Mohd Yunus, 1993; Primack and Lovejoy, 1995 and Anon, 1996). The shrub stratum and ground layer contain not less than 1,300 species of herbs and 70 species of ferns identified to have medicinal values (Mohd Hizamri, 1993).

To achieve SFM, Malaysia has committed to maintain at least $50 \%$ of her land area under forest and tree cover in perpetuity as pledged under the 1992 Rio Earth Summit. This is attained through the protection of forests and the application of Sustainable Forest Management (SFM) practices. According to Malaysia's Second National Communication to the UNFCCC, $56 \%$ of the country was covered in forests in 2000 and $55 \%$ remained covered by 2007 (NRE, 2011) and forest cover in 2012 is estimated to be closer to $53 \%$. These figures include permanent reserve forests, state land forests, national parks and wildlife and bird sanctuaries (NRE, 2011). Out of the total forested area in Malaysia equalling 18.3 million hectares, Sarawak has 8.07 million hectares, Sabah has 4.36 million hectares and Peninsular Malaysia has 5.87 million hectares (NRE, 2011). Statistics from the Food and Agricultural Organisation of the United Nations, reports that national forest and tree cover in 2010 equals $62 \%$ of the total land area (FAO, 2011).

Table 1 shows the status of forested areas in Peninsular Malaysia from 2010 to 2013. In 2013, the total forested area in Peninsular Malaysia was about 5.83 million hectares and this represents about $44 \%$ of the total land area of the peninsula. Slightly more than $84 \%$ of the forests are classified as reserved forests and these are areas dedicated permanently for production, protection and amenity purposes.

Table 1: Forested Area in Peninsular Malaysia from 2010 to 2013 (million hectares)

\begin{tabular}{cccccc}
\hline Year & $\begin{array}{c}\text { Permanent } \\
\text { Reserve Forest } \\
\text { (PRF) }\end{array}$ & $\begin{array}{c}\text { State Land Forest } \\
\text { (SLF) }\end{array}$ & $\begin{array}{c}\text { Wildlife } \\
\text { Reserve } \\
(\text { WR })\end{array}$ & $\begin{array}{c}\text { Other Forest } \\
\text { Reserve } \\
\text { (OFR) }\end{array}$ & $\begin{array}{c}\text { Total } \\
\text { Forested } \\
\text { Area }\end{array}$ \\
\hline 2010 & 4.92 & 0.35 & 0.59 & 0.004 & 5.86 \\
2011 & 4.91 & 0.30 & 0.59 & 0.004 & 5.80 \\
2012 & 4.89 & 0.30 & 0.59 & 0.004 & 5.78 \\
2013 & 4.94 & 0.30 & 0.59 & 0.004 & 5.83 \\
\hline
\end{tabular}

Total land area in Peninsular Malaysia: 13.18 hectares.

Source: Forestry Statistics Peninsular Malaysia 2013. 
The three major forest types found in Peninsular Malaysia are inland forest, mangrove forest and peat swamp forest. Of the three forest types, inland forest accounts for more than 92 percent of the total area. Very little of the lowland forest is still left in the country and timber harvesting operation is now concentrated in the hill forests. This type of forest is dominated by tree species belonging to the dipterocarpaceae family

The PRF in Peninsular Malaysia is classified into various functional classes as shows in Table 2. The main aim of the classification is to manage the forest for various forest services and economic important while the forest quality is maintain to ensure the resources are sustainably managed.

Table 2: Classification of PRF by forest functional classes in 2013

\begin{tabular}{lc}
\hline \multicolumn{1}{c}{ Functional Classes } & $\begin{array}{c}\text { Area } \\
\text { (million hectare) }\end{array}$ \\
\hline Timber Production Forest & 2.98 \\
Soil Protection Forest & 0.52 \\
Soil Reclamation Forest & 0.01 \\
Flood Control Forest & 0.01 \\
Water Catchment Forest & 0.83 \\
Forest Sanctuary for Wildlife & 0.07 \\
Virgin Jungle Reserved Forest & 0.03 \\
Amenity Forest & 0.07 \\
Education Forest & 0.02 \\
Research Forest & 0.04 \\
Forest for Federal purposes & 0.02 \\
State Parks & 0.37 \\
\hline
\end{tabular}

Peninsular Malaysia has benefited tremendously from her forest resources. The rich diversity of the forests has contributed direct economic benefits derived from timber products and other non-timber forest produce.

\section{WOOD-BASED INDUSTRIES}

Forests still form a dominant physical landscape of Peninsular Malaysia and the wood-based industries have played a significant role in the socio-economic development of the country. In addition to providing timber for the manufacture and export of many products, forests have assumed an increasing role in providing recreation opportunities for the people as well as contribute towards foreign exchange earnings through tourism related activities.

Table 3 shows the log flow situation in Peninsular Malaysia for the period 2010 to 2013. Total $\log$ production from Peninsular Malaysia, at least for the 2010-2013 period, averaged to about 4.2 million cubic meters per year and annual log production is almost consistent. The major log producers are the East Coast states of Pahang, Kelantan and Terengganu. Average log consumption amounted to about 4.7 million cubic meters per annum. Therefore, there is no substantial difference between the volumes of log produced and consumed. Data also show that Peninsular Malaysia is importing $\log$ on a small scale.

Table 3: Log Flow in Peninsular Malaysia, 2010 - 2013

\begin{tabular}{cccccc}
\hline & \multicolumn{5}{c}{ Year } \\
& $\mathbf{2 0 1 0}$ & $\mathbf{2 0 1 1}$ & $\mathbf{2 0 1 2}$ & $\mathbf{2 0 1 3}$ & Total \\
\hline Log Productions $\left(\mathrm{m}^{3}\right)$ & $4,161,568$ & $4,171,971$ & $4,467,667$ & $4,084,454$ & $16,885,660$ \\
Log Imports $\left(\mathrm{m}^{3}\right)$ & 653,268 & 669,155 & 837,598 & 698,258 & $2,858,279$ \\
TOTAL & $\mathbf{4 , 8 1 4 , 8 3 6}$ & $\mathbf{4 , 8 4 1 , 1 2 6}$ & $\mathbf{5 , 3 0 5 , 2 6 5}$ & $\mathbf{4 , 7 8 2 , 7 1 2}$ & $\mathbf{1 9 , 7 4 3 , 9 3 9}$ \\
Log Consumption $\left(\mathrm{m}^{3}\right)$ & $4,496,430$ & $4,602,311$ & $5,480,992$ & $4,176,734$ & $18,756,467$ \\
Balance $+/-$ & 318,406 & 238,815 & $(175,727)$ & 605,978 & 987,472 \\
\hline
\end{tabular}

Source: Forestry Statistics Peninsular Malaysia 2013. 
The wood-based industry in Peninsular Malaysia has been dominated by three main processing activities, namely sawmilling, plywood and veneer production. In 2013, the number of wood processing mills in Peninsular Malaysia was 2,749 and out of these more than 1,500 are furniture mills, the majority of which are small scaled family owned backyard mills (Table 4 ). The next biggest number of mills is the sawmill that stood at more than 600, followed by moulding at 167 and plywood/veneer at 53. The sawmilling industry, in particular, consumes more than 80 percent of the total $\log$ consumption of the three types of mills.

Table 4: Number of Wood Processing Mills in Peninsular Malaysia, 2013

\begin{tabular}{lc}
\hline \multicolumn{1}{c}{ Types of Mills } & Number \\
\hline Sawmills & 671 \\
Plywood/ Veneer Mills & 53 \\
Moulding Mills & 167 \\
Furniture, Wood Working \& Joinery Mills & 1,829 \\
Blockboard Mills & 1 \\
Chipboard/ Particleboard Mills & 19 \\
Medium Density Fibreboard Mills (MDF) & 9 \\
TOTAL & $\mathbf{2 , 7 4 9}$ \\
\hline
\end{tabular}

Source: Forestry Statistics Peninsular Malaysia 2013.

\section{CONCLUSION}

Sustainable forest management practices are dynamic where changes has to be made in accordance to the needs, demands, knowledge and technologies and not least is the limitation of the management capacity. Same thing goes to the forest itself because forest is a dynamic ecosystem. Complexity of the tropical rainforest where the content and its ecology is still many not known, is another factor demands for continuous enhancement. The forest management in Peninsular Malaysia is moving towards people centric and participation. Peninsular Malaysia has proved her continuously commitment in ensuring the conservation and rehabilitation of the national forest resources by successfully maintaining to date Permanent Reserved Forest (PRF) areas at 4.94 million hectares. This commitment is expressed through the acquisition of the Certificate for Malaysian Criteria and Indicators for Forest Management Certification (Natural Forest) [MC\&I] for the permanent reserved forest. Peninsular Malaysia has contributed a lot in the Malaysian economic development through her forest sector. It is undeniable that there are still lots of forest resources in Peninsular Malaysia that can be explored. With the guide and references from the existing policy, the forest sector in Peninsular Malaysia will continue to play a prominent and important role in the national economy.

\section{REFERENCES}

1. Anon. 1996. Forestry in Peninsular Malaysia. Forestry Department Peninsular Malaysia, Kuala Lumpur, Malaysia.

2. Food and Agricultural Organisation of the United Nations (FAO). 2010. Forest Resources Assessment.

3. Forestry Department Peninsular Malaysia (FDPM). 2009. Forestry Compendium of Peninsular Malaysia 2009. Kuala Lumpur, Malaysia.

4. Forestry Department Peninsular Malaysia (FDPM). 2013. Forestry Statistics Peninsular Malaysia 2013. Kuala Lumpur, Malaysia.

5. ITTO. 1998. Annual Report for 1998. ITTO. Chiang Mai, Thailand.

6. Mohd Hizamri, M.Y. 1993. Kedinamikan dan kekayaan hutan Malaysia (Forest dynamic and biodiversity of Malaysian forests). Forestry Department paper at the Open Auditorium, Bukit Cahaya Seri Alam, Selangor, August 7, 1993. Malaysia.

7. Mohd Yunus, Z. 1993. Determination of the optimum cut and rotation in Malaysian Production Forests: An Economic Approach, MPhil. Thesis, University Of Wales, Bangor, UK, 10-17, 24, 28-30, 59-60, 93-109.

8. NRE. 2011. Malaysia Second National Communication to the UNFCCC. Ministry of Natural Resources and Environment. Putrajaya, Malaysia.

9. Primack, R.B. and Lovejoy, T.E. 1995. Ecology, conservation and management of Southeast Asian Rainforests. Yale University Press, New Haven and London, 5-13, 1927, 41-51.

10. Thang, H.C. 2009. Malaysia Forestry Outlook Study. Working Paper Series. Asia-Pacific Forestry Sector Outlook Study II (APFSOS). Bangkok. Thailand.

11. Weng, C.W. and Norini, H. 2002. Trends in Malaysian Forest Policy. Policy Trend Report 2002.12-28

12. Whitmore, T.C. 1975. Tropical Rain Forests of the Far East. Clarendon Press, Oxford. 